\title{
Additive Manufacturing of a Low-alloyed Engineering Steel
}

\author{
Christin Aumayr ${ }^{1}$, Jan Plat| ${ }^{2}$, Horst Zunko', and Christoph Turk \\ ${ }^{1}$ voestalpine BÖHLER Edelstahl GmbH \& Co KG, Kapfenberg, Austria \\ ${ }^{2}$ Department of Materials Science, Montanuniversität Leoben, Leoben, Austria
}

Received February 7, 2020; accepted February 11, 2020; published online March 5, 2020

\begin{abstract}
Additive manufacturing of steel powders has gained a lot of attention in recent years. In the early stages of Laser Powder Bed Fusion (L-PBF) of steel powders, the well-known materials 1.2709, 316L, and 17-4 PH were used due to their very low carbon content. Yet, since these materials are, on the one hand, quite soft (316L) but, in some cases, too highly alloyed for specific engineering applications (1.2709) on the other hand, also carbon steels are increasingly considered for a use in L-PBF processes. In general, it is well known that carbon limits the weldability of the steel materials. As a rule of thumb, steels with a carbon content below 0.22 wt.- $\%$ are suitable for L-PBF processes without powder bed preheating. This contribution presents a new carbon-steel alloy concept which can be processed by L-PBF without powder bed preheating. Due to the special alloy design, it will be shown that the printed parts are ready-to-use in the as-built state with a well-balanced property relationship of strength, ductility, and impact toughness. Apart from the usability in the asprinted condition, it will also be shown that an additional heat treatment or even a surface hardening process can be used to gain even better material and part properties compared to the as-built condition.
\end{abstract}

Keywords: Case hardening steel, Engineering steel, Laser powder bed fusion, L-PBF, Steel powder, Mechanical properties, Nitriding, Case hardening, Toughness

\section{Additive Fertigung eines niedriglegierten Einsatzstahls}

Zusammenfassung: Die additive Herstellung von Stahlpulvern hat in den letzten Jahren stark an Bedeutung gewonnen. In den frühen Stadien des Laser PulverbettVerfahrens (L-PBF) mittels Stahlpulvern wurden die bekannten Materialien 1.2709, 316 und 17-4 PH aufgrund ihres sehr geringen Kohlenstoffgehalts verwendet. Für be-

C. Aumayr ( $\triangle)$

voestalpine BÖHLER Edelstahl GmbH \& Co KG

Mariazellerstraße 25,

8605 Kapfenberg, Austria

Christin.Aumayr@bohler-edelstahl.at stimmte technische Anwendungen sind diese Werkstoffe jedoch teilweise zu hoch legiert (1.2709) oder weisen zu geringe Härte- und Festigkeitswerte auf. Daher werden zunehmend auch Kohlenstoffstähle für den Einsatz in L-PBF Verfahren in Betracht gezogen. Es ist allgemein bekannt, dass Kohlenstoff die Schweißbarkeit der Stahlwerkstoffe einschränkt. Als Faustregel gilt, dass Stähle mit einem Kohlenstoffgehalt unter 0,22 Gew.-\% für ein L-PBF-Verfahren ohne Pulverbettvorwärmung geeignet sind. In diesem Beitrag wird ein neues Kohlenstoffstahllegierungskonzept vorgestellt, das im L-PBF Prozess ohne Pulverbettvorwärmung verarbeitet werden kann. Aufgrund des speziellen Legierungsdesigns wird gezeigt, dass die gedruckten Teile bereits im "as-built" Zustand mit einem ausgewogenen Eigenschaftsverhältnis von Festigkeit, Duktilität und Zähigkeit einsatzfähig sind. Es wird ebenfalls aufgezeigt, dass durch eine zusätzliche Wärmebehandlung oder ein Oberflächenhärtungsverfahren noch bessere Material- und Bauteileigenschaften im Vergleich zum „as-built"-Zustand erzielt werden können.

Schlüsselwörter: Einsatzhärter, Einsatzstahl, Pulverbettverfahren, Laserauftragsschweißen, Stahlpulver, Mechanische Eigenschaften, Nitrieren, Einsatzhärten, Zähigkeit

\section{Introduction}

Additive manufacturing ( $\mathrm{AM}$ ), especially the Laser Powder Bed Fusion (L-PBF), has gained a lot of attention in the last decades. The L-PBF process is the main technology for the additive manufacturing of metals, in which parts are built up by selectively fusing regions of a powder bed in a layer-upon-layer manner [1, 2]. Fields of application for AM-printed parts can be found in different areas, like the aerospace, automotive, and medical industries as well as in the tooling sector. The Wohlers report of 2017 predicted that aerospace is the leading industry for the AM sector, due to its high demand of lightweight parts [3,4]. Ti-alloys as well as nickel-base alloys are commonly used for aerospace 


\begin{tabular}{|llllllllll}
\hline $\begin{array}{ll}\text { TABLE } 1 \\
\text { Chemical composition of the low-alloyed steel powder determined by ICP-OES and combustion analysis }{ }^{*} \text { ) }\end{array}$ \\
\hline Wt.-\% & $\mathrm{Fe}$ & $\mathrm{C}^{*}$ & $\mathrm{Si}$ & $\mathrm{Mn}$ & $\mathrm{Cr}$ & $\mathrm{Ni}$ & $\mathrm{Mo}$ & $\mathrm{V}$ \\
\hline Böhler E185 AMPO & $\mathrm{Bal}$ & 0.2 & 0.2 & 0.3 & 1.0 & 1.2 & 0.2 & 0.1 \\
\hline
\end{tabular}

\begin{tabular}{|lllll}
\hline TABLE 2 \\
Printing parameters for testing samples used in this study
\end{tabular}

\begin{tabular}{|llll|}
\hline $\begin{array}{l}\text { TABLE } 3 \\
\text { Heat treatment parameters }\end{array}$ & \\
\hline $\begin{array}{l}\text { Böhler E185 } \\
\text { AMPO }\end{array}$ & Temperature & Time & Quenching \\
\hline Hardening & $850^{\circ} \mathrm{C}$ & $30 \mathrm{~min}$ & Water quenching \\
\hline Tempering & $200^{\circ} \mathrm{C}$ & $2 \mathrm{~h}$ & Air cooling \\
\hline
\end{tabular}

applications when it comes to the need of high temperature strength and oxidation resistance $[3,5]$. Aerospace lightweight components frequently have complex geometries, and the used materials often show difficult mechanical workability. Because of this and also because of the small amount of required parts, the AM technology is suitable for this sector [6]. In contrast, the AM technology is not well established in the automotive industry, since the AM process is not economically profitable for this kind of mass production [3]. Haeckel et al. [7] pointed out that the lot sizes as well as the pressure on costs are higher for the automotive industry than for the aerospace industry. Yet, the ongoing development and optimization of the printing process will provide a higher increase in productivity and thereby lower costs in the near future. The tested materials of Haeckel et al.'s study are the grades 1.2709 and AISi10Mg, which will be discussed in this work as the common materials for AM in the automotive industry [7]. In general, the most common materials for engineering applications are the alloys 17-4 PH and the 316L. These AM alloys have been extensively investigated in terms of printing parameters, microstructure, and mechanical properties [5]. These alloys were developed as bar material and not specially designed for the AM technology. Since the L-PBF process is a welding technology, however, new alloys dedicated to micro welding processes will show enhanced properties compared to materials used for a conventional production. In this study a new alloy will be presented which is preferentially designed for AM production. The newly developed Böhler E185 AMPO [8] alloy can be classified as a case hardening steel. These types of low-alloyed carbon steels are commonly used in the automotive industry, e.g. for the production of gears or shift forks [3]. This contribution shows that this new AM-grade exhibits easy printability and fast build up rates, which are crucial for the economic use in rapid prototyping by L-PBF. Besides this, the alloy provides the possibility to be used in the as-printed and also in heattreated condition. Since the Böhler E185 AMPO can be case hardened, this contribution gives a short outlook on the technological possibility to enhance the surface hardness of this AM material.

\section{Experimental}

The low-alloyed steel powder has been produced by voestalpine Böhler Edelstahl GmbH \& Co KG, Kapfenberg, Austria, by vacuum induction melting and Ar-gas atomization, followed by a classification process by sieving and protective-Ar-gas classification. The chemical composition of the powder has been determined by ICP-OES (inductively coupled plasma optical emission spectrometry) and combustion analysis ${ }^{*}$ according to DIN EN ISO 15350 to measure the carbon content. The measured elements are listed in Table 1.

The powder characterization includes the measurement of the particle size distribution (PSD), the sphericity, and the flowability as well as the apparent density. According to DIN EN ISO 13322-2, the PSD as well as the sphericity were determined by the dynamic image analysis method with a Camsizer XT. The flowability and the apparent density are measured with a Hall flowmeter according to DIN EN ISO 4490 respectively in the Carney flowmeter according to ASTM B964. The print jobs were carried out with an EOS M290 machine without powder-bed pre-heating. The used printing parameters for this study are given in Table 2.

Porosity measurements and the microstructure were determined by using a light optical microscope (LOM) Olympus BX53M. For the microstructure investigations, the etchant Nital $2 \%$ was used. For the mechanical characterization of the AM-processed material, tensile samples with the dimension of $\varnothing 15 \times 85 \mathrm{~mm}^{3}$ and impact samples with the dimension of $12 \times 12 \times 57 \mathrm{~mm}^{3}$ have been built in the horizontal as well as in the vertical direction to the building platform. The mechanical properties were evaluated in the "as printed" condition as well as in the hardened and tempered condition. For the austenitization a vacuum furnace of the type Schmetz IU 54/1F 2R was used and the subsequent annealing process was carried out in a Nabertherm N60/85 HA chamber furnace. The detailed parameters for the heat treatment are given in Table 3. After the heat treatment, the samples were machined to their final shape according to ASTM 8 and ASTM 23. Tensile testing was carried out on a Zwick Roell/Beta 200 machine, impact tests were done by a Zwick Roell PSW 750 TZE HA and the hardness was measured with an Emco Test M4R 02563 . The alloy also exhibits the potential to be optimized in terms of higher surface hardness and wear resistance. Therefore, case hardening, gas and plasma nitriding treatments were carried out. The parameters for these surface treatments are given in Table 4. 


\begin{tabular}{|lll|}
\hline $\begin{array}{l}\text { TABLE } 4 \\
\text { Parameters for case hardening, gas and plasma ni- } \\
\text { triding }\end{array}$ & \\
\hline Böhler E185 AMPO & Temperature & Time \\
\hline Case-hardening & $930^{\circ} \mathrm{C}$ & $2.5 \mathrm{~h}$ \\
\hline Plasma nitriding (PN) & $525^{\circ} \mathrm{C}$ & $8 \mathrm{~h}$ \\
\hline Short time gas-nitriding (STN) & $575^{\circ} \mathrm{C}$ & $4 \mathrm{~h}$ \\
\hline Long-time gas-nitriding (LTN) & 1. step $530^{\circ} \mathrm{C}$ & $32 \mathrm{~h}$ \\
\cline { 2 - 3 } & 2. step $545^{\circ} \mathrm{C}$ & $4 \mathrm{~h}$ \\
\hline
\end{tabular}

\section{Results and Discussion}

The powder characteristics of the Böhler E185 AMPO powder used in this study are listed in Table 5.

The power particles, shown in Fig. 1a, exhibit a spherical morphology with a small amount of satellites. The spherical morphology is also represented in the sphericity value of 0.92 given in Table 5. Moreover, the apparent density of the powder shows a typical value for steel powders of $\sim 3.7 \mathrm{~g} / \mathrm{cm}^{3}[9,10]$. In addition, the particle size distribution shows nearly a Gaussian distribution profile with the powder diameter values. The particle size distribution is displayed in Fig. 1b.

Prior to the printing of the samples, a detailed DOE-study was carried out to ensure a high relative density above $99.98 \%$ of the printed material. Fig. 2a shows a LOM picture of a polished sample in the z-direction. No inclusions or lack of fusion defects are visible, and only few pores could be detected. These results are indicators for the easy printability of the material. In Fig. $2 \mathrm{~b}$ the process window marks a wide area in which the material is printable to a relative density higher than $99.98 \%$. Due to the wide range of feasible parameter combinations, it is possible that the AM-operators gain more freedom in designing the process parameters for each individual geometry. The restriction to stick to one specific parameter setting could negatively affect the reachable quality of the AM part in terms of density.

The microstructure was evaluated of polished samples using LOM. In the as printed condition, the Böhler E185 AMPO consists of a martensitic-bainitic microstructure (Fig. 3a). The typical welding structure could be detected, and in addition, the printed layer thickness corresponds well to the used powder layer thickness of $40 \mu \mathrm{m}$ (Table 2). Fig. $3 \mathrm{~b}$ shows the microstructure in a higher magnification. The martensitic-bainitic microstructure is typical for these kind of steels after rapid cooling. Wang et al. [9] investigated the microstructure of an AISI 4140 steel material, which was also manufactured by L-PBF, and detected also a fine martensitic-bainitic microstructure. This fine microstructure is caused by the micro welding manufacturing method. Due to the very fast process of melting and solidification with a high cooling rate, the L-PBF process causes a finer microstructure, compared to conventional produced materials with the same chemical composition [11].

Due to the fine-grained martensitic-bainitic microstructure, it was expected that the mechanical properties of this material would also be exceptional. The results of the mechanical tests are displayed in Fig. $4 a$, b. It could be seen that the Böhler E185 AMPO has a well-balanced property relationship of strength, hardness, ductility, and impact toughness in the as printed condition. Without any heat treatment, it is possible to gain strength values of up to $1200 \mathrm{MPa}$, a hardness level of about $38 \mathrm{HRc}$, an elongation (A5) of about $15 \%$, and a reduction of area (Z) of $70 \%$. The impact toughness measured by Charpy $V$-notched impact samples reaches values up to $140 \mathrm{~J}$ at room temperature. Also the testing of the impact toughness at $-20^{\circ} \mathrm{C}$ shows very promising results of $120 \mathrm{~J}$. Comparing the tested impact toughness of Böhler E185 AMPO with the results of Wang et al., which is represented by $35 \mathrm{~J}$ at $-18^{\circ} \mathrm{C}$, the newly developed alloy has a four times higher toughness [9]. If

\begin{tabular}{|llllll}
\hline $\begin{array}{l}\text { TABLE } 5 \\
\text { Powder characteristics }\end{array}$ & & & & \\
\hline $\begin{array}{l}\text { Flowability } \\
\text { Carney flow }\end{array}$ & Sphericity & Apparent density & D10 & D50 & D90 \\
\hline $3 \mathrm{~s} / 50 \mathrm{~g}$ & 0.92 & $3.77 \mathrm{~g} / \mathrm{cm}^{3}$ & $20.4 \mu \mathrm{m}$ & $31.0 \mu \mathrm{m}$ & $43.7 \mu \mathrm{m}$ \\
\hline
\end{tabular}

Fig. 1: a SEM-picture of the Böhler E185 AMPO powder and $\mathbf{b}$ PSD-curve of the investigated powder
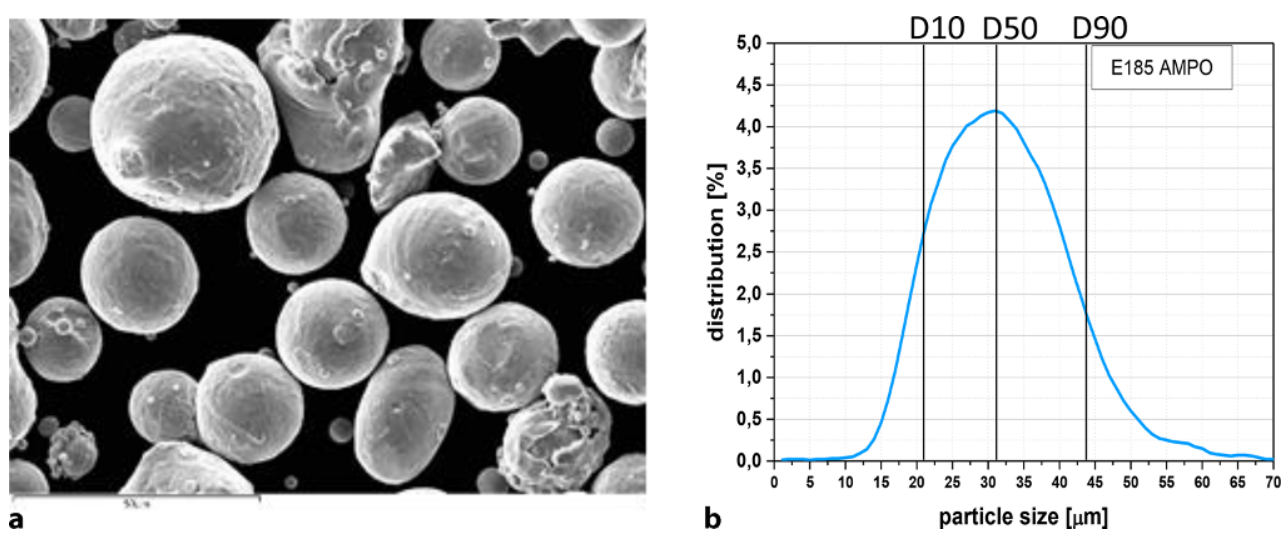
Fig. 2: a LOM-picture of the printed BöhlerE185AMPO and b process window, in which a relative density higher than $99.98 \%$ can be achieved

Fig. 3: a Microstructure of the BöhlerE185 AMPO in the as printed condition and $\mathbf{b}$ microstructure with a higher magnification

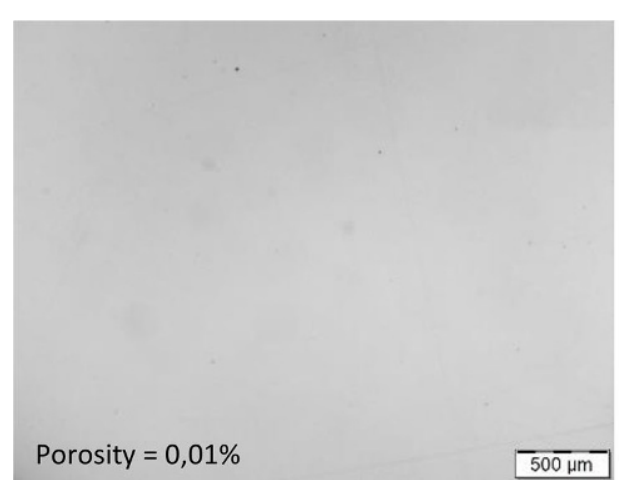

a

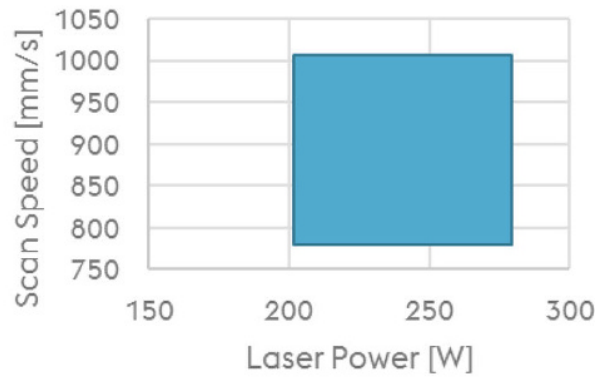

b

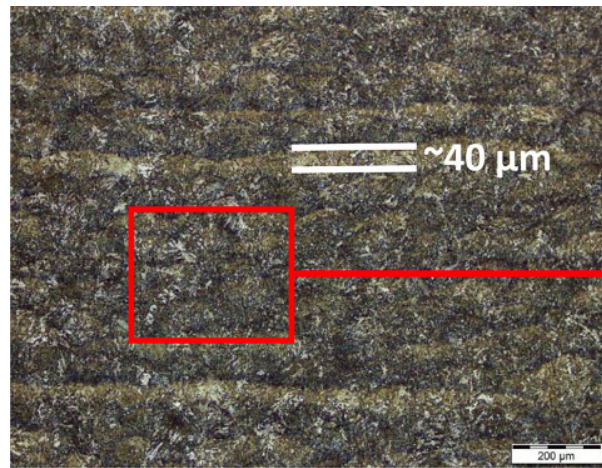

a

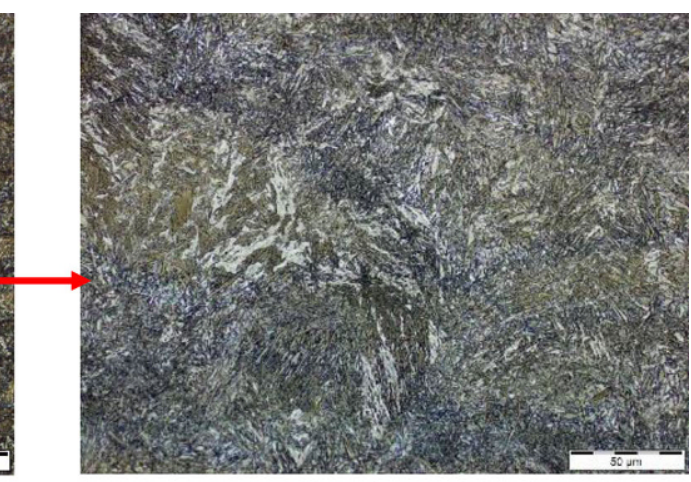

b
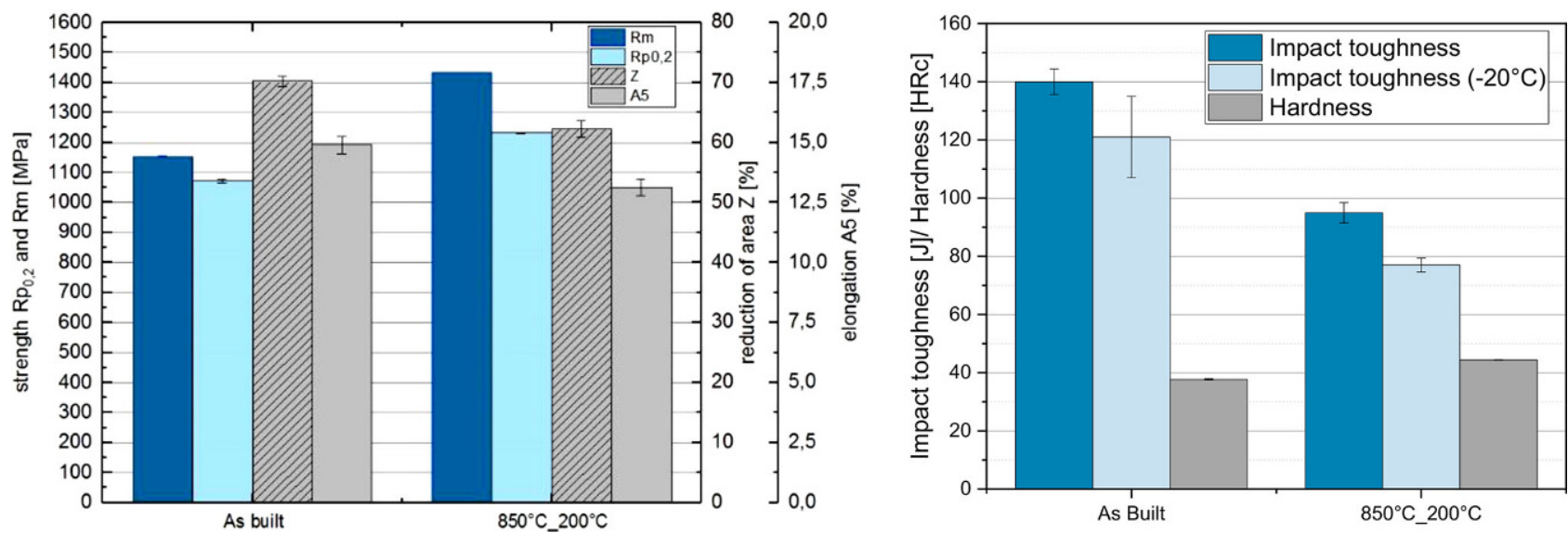

Fig. 4: a Results of tensile tests and $\mathbf{b}$ results of impact toughness (room temperature and $-20^{\circ} \mathrm{C}$ ) and hardness tests

a higher strength or hardness is necessary, however, a simple heat treatment could be carried out.

The heat treatment leads to changes in the microstructure and the mechanical properties. After the quenching and tempering process, an increase of the strength up to $1400 \mathrm{MPa}$ is possible as well as an increase in hardness up to $44 \mathrm{HRc}$ with only a small decrease of the ductility values A5 and Z. Yet, the impact toughness decreases to values of about $95 \mathrm{~J}$, but still those values are much higher compared to the results of Wang et al. [9] where $30 \%$ of the toughness of Böhler E185 AMPO was reached. After the heat treatment, the printed sample will be completely homogenized and no welding structure is evident anymore.
The microstructure of the samples after heat treatment can be seen in Fig. 5a and, in a higher magnification, in Fig. 5b. The alloy shows a fine martensitic structure with a small amount of bainite.

Since low-alloyed C-steels are usually surface hardened, an evaluation of the ability to case hardening $(\mathrm{CN})$, gasnitriding, and plasma-nitriding was carried out. The results are discussed and compared to those of $16 \mathrm{MnCr} 5$ (DIN ISO 1.7131) bulk material, a typical case hardening steel (Fig. 6; [3]). The $16 \mathrm{MnCr} 5$ was hardened and nitrided originating from soft annealed condition, and the Böhler E185 AMPO was treated starting from the as printed condition. The parameters for the treatments are given in Table 4. 
Fig. 5: a Microstructure of the BöhlerE185AMPO in the heat treated condition and b microstructure with a higher magnification
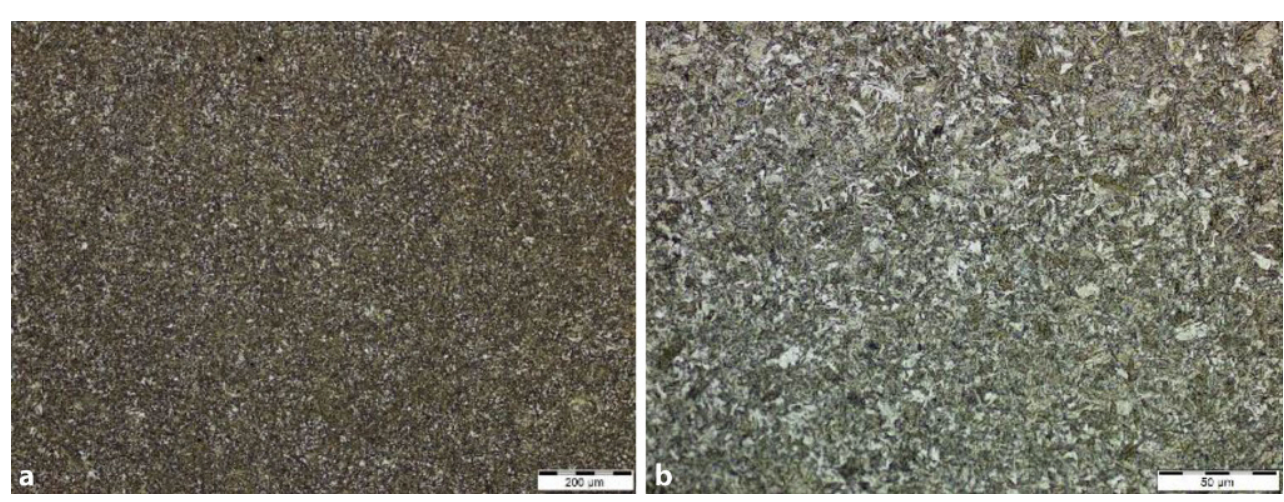
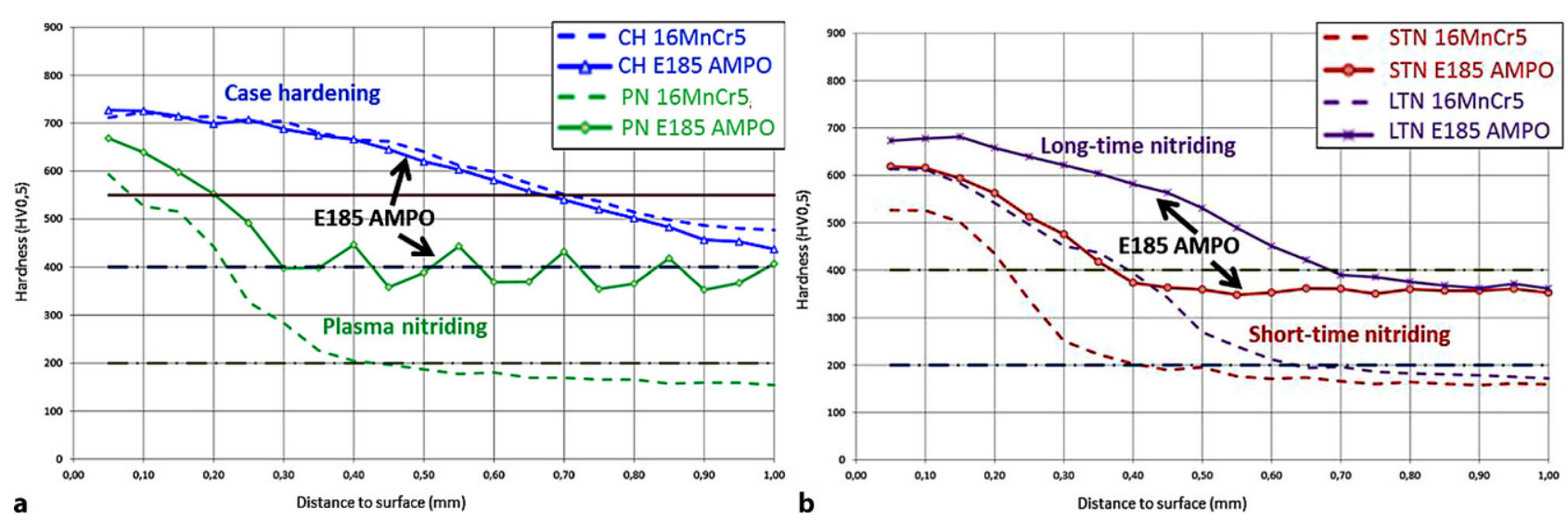

Fig. 6: a Hardness profiles ofBöhlerE185AMPO (printed) and 16MnCr5 (bulkmaterial) after case hardening and plasma nitriding and b hardness profiles of Böhler E185 AMPO (printed) and 16MnCr5 (bulk material) after gas nitriding

Regarding the case hardenability, both materials are on the same level. The achievable hardness on the surface is $720 \mathrm{HV} 0.5(\sim 61 \mathrm{HRc})$. The results for plasma nitriding, however, show that the Böhler E185 AMPO has a higher surface hardness of about $675 \mathrm{HV} 0.5$ ( $59 \mathrm{HRc})$ compared to $16 \mathrm{MnCr} 5$ with about $600 \mathrm{HV0.5}$ ( $55 \mathrm{HRc})$. The same trend can be found if the two materials are gas nitrided. From that it can be concluded that the hardness profile of the Böhler E185 AMPO for all nitriding variants is at a significantly higher level compared to the $16 \mathrm{MnCr} 5$ bulk material. This increased hardness and hardenability can be attributed to the special alloy concept of this new alloy (Table 1).

\section{Summary and Outlook}

This study gives an overview about the characteristics of a newly developed low-alloyed C-steel powder for AM. The main results are summarized as follows:

- The powder quality exhibits state-of-the-art properties in terms of morphology, PSD, and flowability.

- The material shows an easy printability without the need of powder bed preheating. Relative density values of above $99.98 \%$ can be reached.

- The material can be used in the as printed condition due to a well-balanced property relationship of strength, duc- tility and impact toughness and is therefore suitable for rapid prototyping applications.

- A tailoring of properties is possible by a simple heat treatment, case hardening, and gas- or plasma-nitriding processes.

- Further work on the mechanical and technological properties such as fatigue testing, physical properties, and additional surface treatments like PVD-coatings will studied in future work.

Open Access This article is licensed under a Creative Commons Attribution 4.0 International License, which permits use, sharing, adaptation, distribution and reproduction in any medium or format, as long as you give appropriate credit to the original author(s) and the source, provide a link to the Creative Commons licence, and indicate if changes were made. The images or other third party material in this article are included in the article's Creative Commons licence, unless indicated otherwise in a credit line to the material. If material is not included in the article's Creative Commons licence and your intended use is not permitted by statutory regulation or exceeds the permitted use, you will need to obtain permission directly from the copyright holder. To view a copy of this licence, visit http://creativecommons.org/licenses/by/4.0/.

\section{References}

1. Wang, X.; Muniz-Lerma, J. A.; Sánchez-Mata, O.; Shandiz, M. A.; Brochu, M.: Microstructure and mechanical properties of stainless steel $316 \mathrm{~L}$ vertical struts manufactured by laser powder bed fusion process, Material Science\& Engineering A, 736 (2018), pp 27-40 
2. ASTM, ISO/ASTM52900-15, Standard Terminology of Additive Manufacturing-General Principles-Terminology, ASTM International, West Conshohocken, PA, 2015

3. Wohlers Associates Inc., Wohlers Report 2017: 3D Printing ans Additive Manufacturing State of the Industry Annual Worldwide Progress Report, Colorado, USA, 2017

4. Schmitt, M.; Schlick, G.; Seidel, C.; Reinhart, G.: Examination of the processability of $16 \mathrm{MnCr} 5$ by means of laser powder bed fusion, Procedia CIRP, 74 (2018), pp 76-81

5. Herzog, D.; Seyda, V.; Wycisk, E.; Emmelmann, C.: Additive manufacturing of metals, Acta Materialia, 117 (2016), pp 371-392

6. Satish Prakash, K.; Nancharaih, T.; Subba Rao, V. V.: Additive Manufacturing Techniques in Manufacturing-An Overview, Materials Today: Proceedings, 5 (2018), pp 3873-3882

7. Haeckel, F.; Meixlsperger, M.; Burkert, T.: Technological challenges for automotive series production in laser beam melting, Solid freeform fabrication 2019. Proceeding of the 28th annual international solid freeform fabrication symposium - an additive manufacturing conference reviewed paper, 2019

8. voestalpine Böhler Edelstahl GmbH \& Co KG, BÖHLER E185 AMPO, Product Data Sheet, 2019

9. Wang, W.; Kelly, S.: A Metallurgical Evaluation of the Powder-Bed Laser Additive Manufactured 4140 Steel Material, The Minerals, Metals\& Materials Society, JOM, 68 (2016), no.3, pp 869-875

10. EOS GmbH, EOS StainlessSteel 17-4PH, Product Data Sheet, EOS M 290 IndustryLine, 2017

11. Hanzl, P.; Zetek, M.; Baksa, T.; Kroupa, T.: The Influence of Processing Parameters on the Mechanical Properties of SLM Parts, Procedia Engineering, 100 (2015), pp 1405-1413

Publisher's Note. Springer Nature remains neutral with regard to jurisdictional claims in published maps and institutional affiliations. 